Canadian Journal of Family and Youth, 11(1), 2019, p. 441

ISSN 1718-9748@ University of Alberta

http://ejournals,library,ualberta.ca/index/php/cjfy

\title{
Boys and Patriarchy
}

\author{
Terry Trowbridge, York University
}

\begin{abstract}
This poem examines some of the feelings of paternalism the author had for small lizards, insects, and arachnids that he encountered in the forests of the Niagara Escarpment, when he was in early grade school. As a child, unrequited feelings of paternalism made the world of non-domesticated animals a mystery. Only later in adult life did he interrogate these early memories of encounter with animals as part of a gendered society.
\end{abstract}

Boys and Patriarchy

A boy lifted up a rock and found a salamander.

He picked the salamander up and wanted it to

hold onto his finger for safety,

or crawl up his arm for protection.

The boy wanted to be a protector, as if any

animal could be a pet, the situation an easy switch to flick.

He thought that under the rock was a damp wilderness

and once caught the salamander would surrender to the new facts,

with an expectation of petting and being provided for.

The salamander escaped with a whip around the fingers.

Left behind was a wet black line and cold blood

marking the place on the boy's hand where

the salamander decided it was worth sacrificing a tail.

The salamander thought it left the tail behind.

That night, the boy thought he left the salamander behind. 